\title{
Influence of Crossbreeding of Ghezel Ram With Grey Shirazi Ewe on Growth Performance, Feed Efficiency and Carcass Traits of Fattening Lambs
}

Abdolhamid Karimi ( $\square$ ab.karimi@areeo.ac.ir )

AREEO: Agricultural Research Education and Extension Organization

Mohammad Javad Abarghuei

AREEO: Agricultural Research Education and Extension Organization

Alidad Boostani

AREEO: Agricultural Research Education and Extension Organization

\section{Research Article}

Keywords: Carcass traits, Crossbreeding, Fattening lambs, Ghezel, Grey Shirazi

Posted Date: July 7th, 2021

DOI: https://doi.org/10.21203/rs.3.rs-642724/v1

License: (c) (i) This work is licensed under a Creative Commons Attribution 4.0 International License.

Read Full License 


\section{Abstract}

In this investigation, performance, feed efficiency and carcass traits of 48 weaned crossbred Grey Shirazi $\times$ Ghezel and purbred Grey Shirazi fattening lambs (mean live weight, $28.5 \pm 0.5 \mathrm{~kg}$ and age, $115 \pm 5$ days) were evaluated. Lambs were divided into 4 groups contain the GM group (12 purebred male lambs of Grey Shirazi ewe $\times$ Grey Shirazi ram), the GF group (12 purebred female lambs of Grey Shirazi ewe $\times$ Grey Shirazi ram), the CM group (12 crossbred male lambs of Grey Shirazi ewe $\times$ Ghezel ram) and the CF group (12 crossbred female lambs of Grey Shirazi ewe $\times$ Ghezel ram). The dry matter intakes (DMI), average daily gain (ADG) and carcass traits in the lambs were determined. The DMI was greater in CF lambs compared to GF lambs $(P<0.001)$. Feed conversion ratio (FCR) was higher in male lambs comparing to female lambs $(P=0.001)$. The final body weight, $A D G$, live weight at the slaughtering and hot carcass weight (HCW) were lower in GF lambs compared to another lambs $(P<0.001, P=0.003)$. Cold carcass weight (CCW) in CM lambs was higher than in other groups. The Longissimus dorsi (LD) area was higher in crossbreed male lambs $(P=0.001)$. Crossbreeding improved grow performance (final body weight and $A D G$ ) in male and female lambs. Carcass trait was improved by crossbreeding especially in male lambs. Sex effect on growth performance and carcass traits was noticeable and male lambs had superior growth.

\section{Introduction}

The main purpose of sheep breeding is increasing production mostly growth performance and improving reproductive traits (Seyedsharifi and Hamzehzadeh 2016) and this aim can be improved by genetic, nutrition, health condition and management. Improving of genetic traits of sheep could be done by different methods such as selection, presenting fresh sires, inbreeding, crossbreeding, formation of new breed and blend of these procedures (Notter et al. 2014; Blasco et al. 2019).

Crossbreeding has been experienced for several decades in sheep to create breeds with the best traits (Mahmoud Marai et al. 2009; Caro et al. 2018). This method used to improve animal breeds with high maturity, low feed efficiency and low meat production (Caro- Petrović et al. 2015). Abdullah et al. (2010) showed that crossing Awassi with exotic breeds improved growth performance and productivity. Similarly, Kutluca Korkmaz and Emsen (2016) reported improvement in growth from crossbreeding of the fat-tailed Morkaraman and Romanov breeds.

Additionally, genotype can be effective on carcass traits of sheep. Crossbreeding by decreasing the total body fat can improve carcass traits of fat tailed breeds (Khaldari and Ghiasi 2018). Results of another study displayed that crossing between Chaal (fat tailed) and Zel (tailed sheep) breeds increased quality of meat and reduced amount of muscular fat compared to pure breeds (Kashan et al. 2005).

The Grey Shirazi sheep is native breed of Fars province of Iran and it is moderate fat-tail in conformation and could be classified as a medium breed and has an average body weight of $45-55 \mathrm{~kg}$ for ewe and 70-80 kg for ram. This breed has 3 colors, black, brown and gray. Grey lambs are famous for fur 
production and are slaughtered in age of 3-10 days. However, nowadays these sheep are kept for producing meat (Karimi and Rahmani 2017). This breed is originally a range sheep and well adapted for utilizing low quality feed under adverse environmental conditions in Iran and have a not high growth rate (Makarechian et al. 1978).

Origin of the Ghezel sheep in Iran is Azarbayjan region. This area has arid and cold mountain weather. This sheep is fat tailed breed and could be classified as a heavy breed and has an average body weight of 55-65 kg for ewes and 85-90 kg for rams. This sheep is growing for meat and wool production and the wool color is red and has pieces of dark and bright red. This breed is a farm sheep and has been raised under better environmental condition and has an approximately high growth rate (Nasiriyan et al. 2009; Hosseinzadeh et al. 2016).

Ghezel sheep is classified as a heavy breed and have better growth rate compared to Grey Shirazi breed and it was hypothesized that crossbreeding the Gray ewes and Ghezel rams may improve the growth performance of the crossbred offspring. Since the effect of crossbreeding the Grey Shirazi and the Ghezel breeds on male and female lamb's performance has not been investigated yet, this work was done to assess the impact of crossbreeding Grey Shirazi ewe and Ghezel ram breeds on growth performance and carcass traits.

\section{Materials And Methods}

\section{Crossbreeding, experimental groups and feeding}

This investigation was carried out according to The Care and Use of Agricultural Animals in Research and Teaching guidelines at the Fars Agricultural and Natural Resources research and Education Center, Shiraz, Iran.

A total of 180 Grey Shirazi ewes belonging to the Fars Agricultural and Natural Resources research and Education Center, Shiraz, Iran, were used for this study. Two separate place breeding was created. In first place, breeding between Ghezel rams ( $n=6$, live weight of $88 \pm 3 \mathrm{~kg}$, age average $2.5 \pm 0.5$ years old) with Grey Shirazi ewes ( $n=90$, live weight of $45 \pm 5 \mathrm{~kg}$, age average $2.5 \pm 0.5$ years old) and in second place breeding between Grey Shirazi rams ( $n=6$, live weight of $75 \pm 3 \mathrm{~kg}$, age average $2.5 \pm 0.5$ years old) with Grey Shirazi ewes ( $n=90$ live weight of $45 \pm 5 \mathrm{~kg}$, age average $2.5 \pm 0.5$ years old) was done. The ratio of ram to ewe was 1:15 in each flock and allowed ability to fresh water and mineral blocks. The concentrate composition was $40 \%$ barely grain, $30 \%$ corn grain, $27.5 \%$ wheat bran, $0.5 \%$ calcium carbonate, $1 \%$ salt and $1 \%$ vitamin mineral premix. After mating, the rams separated and ewes in each flock were kept separately. After lambing, ewes and theirs lambs were numbered and lambs were kept with mothers until weaning. Average birth weight of lambs in purebred and crossbred flocks were $4.5 \pm 0.3 \mathrm{~kg}$ and $5.0 \pm 0.2$ $\mathrm{kg}$ respectively. Afterwards the lambs in each group were kept in the similar conditions until selection time for present experiment. For the main study, 48 weaned lambs (live weight of $28.50 \pm 0.5 \mathrm{~kg}$ and 115 \pm 5 days of age) (24 male and 24 female lambs) were taken randomly from the each flock and were penned individually in separately cages. Lambs were divided into 4 groups (treatments) (12 lambs per 
each group). The GM group (12 purebred male lambs of Grey Shirazi ewe $\times$ Grey Shirazi ram), GF group (12 purebred female lambs of Grey Shirazi ewe $\times$ Grey Shirazi ram), CM group (12 crossbred male lambs of Grey Shirazi ewe $\times$ Ghezel ram) and CF group (12 crossbred female lambs of Grey Shirazi ewe $\times$ Ghezel ram). Animals were permitted 14 days adaptation. At the beginning of the adaptation diet, all the lambs were cured for external and internal parasites and immunized against enterotoxaemia. The animals were fed to meet requirements according to NRC (2007). The formulated diet contained $13.49 \%$ $\mathrm{CP}$ and $2.40 \mathrm{Mcal} \mathrm{ME} / \mathrm{kg} \mathrm{DM}$ for $\mathrm{ADG}$ of $250 \mathrm{~g} / \mathrm{d}$ and the percent of forage to concentrate ratio was $47: 53 \%$ of DM. The lambs were nourished two times every day (08:15 and 17:15 h) ad libitum to ensure $5 \%$ orts and with allowed ability to fresh water and mineral-vitamin bricks. In the all days before morning feed meal, surplus feed of the earlier day was gathered and the orts were measured.

\section{Growth performance}

Lambs weight was measured each 15-d intervals during $90 \mathrm{~d}$ of the experiment. Body weight was measured for each separate lamb prior to morning feed meal. The ADG was determined for each lamb from day 1 to day 90. Feed conversion ratio (FCR) was calculated as the ratio between DMI and ADG.

\section{Carcass traits}

At the finish of the trial days, lambs were weighed after $16 \mathrm{~h}$ fasting. Lambs were slaughtered separately by cutting the arteries and the jugular vein in the neck region and were allowed to whole bleeding (Farid 1991). Then the lamb's skins were separated and weights of skin, head and feet were recorded. The internal organs such as rumen, kidneys, lungs, spleen, heart and liver were separated and weighed. The internal fat content was completely separated and weighed. Gut digestive contents were removed and empty body weight was determined by detracting these contents from body weight. The hot carcasses of each lambs were weighed and carcasses were kept at refrigerator (temperature of $4{ }^{\circ} \mathrm{C}$ for $24 \mathrm{~h}$ ). Then weight of cold carcasses was measured. The cold carcasses halved cautiously (Farid 1991). Commercial Iranian cuts performed for halving. The cuts on the left side of each carcass were stored at $-20^{\circ} \mathrm{C}$. The commercial cuts were neck, brisket, thigh, hands, flank, loin, fat tail. For these sections subcutaneous fat in excess of $5 \mathrm{~mm}$ was removed, deboned and the weight of each section was recorded. Fat trim and meat tissue from each wholesale cut were combined, ground twice, thoroughly mixed, and samples of approximately $100 \mathrm{~g}$ were taken. The samples were packed and frozen at $-20^{\circ} \mathrm{C}$ for subsequent chemical analysis.

Carcasses were cut between rib 12 and 13 and width and depth of rib eye area (Longissimus dorsi, LD area) were measured on the left cut carcass (Esenbuga et al. 2009). The back-fat thickness was measured in 2 points above section of the LD. The LD area was measured by acetate paper and planimeter. The maximum depth and width of LD was measured by digital coulis. Tight, hand, neck, loin, brisket, flank, fat tail, total fat half-carcass without fat tail, total fat half-carcass with fat tail, leans and bones were separated and weighed (Farid 1991).

\section{Laboratory analyses}


The samples of consumed ration and orts were dried by oven at $60^{\circ} \mathrm{C}$ for $48 \mathrm{~h}$ and were ground in size of $1 \mathrm{~mm}$. Dry matter of samples was measured using oven drying at $105^{\circ} \mathrm{C}$ for $16 \mathrm{~h}$ (AOAC 1990; method 930.15). The amount of Ash was measured using burning of samples at $550{ }^{\circ} \mathrm{C}$ for $12 \mathrm{~h}$. Organic matter content was calculated as difference between sample weight and ash content (AOAC 1990; method 942.05). The NDFom was determined by method of Van Soest et al. (1991). ADFom content was determined according to AOAC (1990; method 973.18). Lignin was measured by solubilization of cellulose with sulfuric acid (Robertson and Van Soest 1981). Nitrogen content was measured by the Kjeldahl device (AOAC 1990; method 954.01).

For meat chemical analysis, moisture, ash, ether extract (EE) and crude protein (CP) were determined according to the AOAC (1990) methods.

\section{Statistical analyses}

Data were analyzed using the general linear model with a completely randomized design considering genotype, sex and genotype $\times$ sex interaction as variables. Data was analyzed by the SAS (2001) software and using the initial weight as a covariate. The means treatments were compared by Tukey's test with $5 \%$ probability level.

$Y_{i j k}=\mu+G_{i}+S_{j+} G S_{i j+} 1(\mathrm{Cov}) \mathrm{m}+e_{i j k}$

Where $Y_{i j k l}$ is the overall observation, $\mu$ the overall mean, $G_{i}$ the ith effect of genotype, $S_{j}$, the jth effect of sex, $G S_{i j}$ the interaction of genotype and sex, $1(\mathrm{Cov}) \mathrm{m}$ the covariate effect and $e_{i j k}$ the standard error term.

\section{Results}

\section{Growth performance and dry matter intake}

The voluntary consumption of DM was significantly higher in CM and CF compared to GM and GF ( $P<$ 0.0001) (Table 2) but difference in male and female lambs was not significant. The final BW and ADG in $\mathrm{CM}$ and $\mathrm{CF}$ lambs were higher than those for GM and GF lambs ( $P=0.0005$ and $P=0.002$ respectively) (Table 2). The final BW among crossbred male lambs was higher than crossbred female lambs $(P=$ $0.011)$ but among purebred male and female lambs was not different. The ADG between $C M$ and $C F$ and between GM and GF was different and in males lambs was higher than female lambs $(P=0.003)$. The FCR between CM and GM lambs and between CF and GF lambs was not different; while, this parameter was lower in $\mathrm{CM}$ and GM lambs comparing to CF and GF lambs $(P<0.0001)$.

\section{Carcass traits data of crossbreed and non-crossbreed lambs}

The HCW in CM lambs was higher compared to GM lambs $(P=0.0007)$ but this weight was not different between CF and GF. The HCW in crossbred male lambs was greater compared to crossbred female lambs $(P=0.021)$. The amount of CCW in CM and CF lambs was greater than in GM and GF groups $(P=0.001)$. 
The CCW in crossbred male lambs was greater compared to crossbred female lambs $(P=0.025)$. In GF and CF lambs, IFW was higher than in GM and CM lambs $(P=0.0001)$. Internal fat weight as percent of live body weight in female lambs (GF and CF) was higher than in male lambs (GM and CM) $(P<0.0001)$. Total of hard drops and components containing hide, head and feet in female lambs (GF and CF) were lower than in male lambs (GM and $\mathrm{CM})(P<0.0001)$ but noteworthy difference between $\mathrm{GM}$ and $\mathrm{CM}$ lambs and between GF and CF lambs was not observed. Weight of head in GM lambs was higher than CM lambs. Total of soft drops $(P=0.0002)$ and components containing kidneys $(P=0.0001)$ and liver $(P$ $<0.0001$ ) in female lambs (GF and CF) were lower than in male lambs (GM and CM). Weight of spleen and heart in GM lambs were lower than $\mathrm{CM}$ lambs $(P=0.003$ and $P<0.0001$ respectively). Thigh, hand and loin weights in GM was lower than in $\mathrm{CM}(P=0.003, P=0.004$ and $P=0.005$ respectively) but difference between GF and CF was not significant for this parameters. Weights of brisket and flank and thigh, hand, loin and brisket weights as a percent of cold half-carcass were not different among experimental lambs. Neck and Neck weight as a percentage of cold half-carcass weight in GM lambs were lower than in CM lambs but these parameters had no significant difference in GF and CF lambs. Neck and Neck weight as a percentage of cold half-carcass weight in crossbred male lambs were higher than their females but these parameters in purebred male and female lambs were not different.

Lean weight only in purebred and crossbred male lambs was different $(P=0.0006)$ but in female lambs was not diverse. Lean weight and lean weight as a percentage of cold half-carcass weight in crossbred male lambs were greater than female lambs $(P=0.0004$ and $P=0.004$ respectively). Bone weight in GM and GF lambs was lower than CM and CF lambs $(P=0.0003)$. The LD area $\left(\mathrm{cm}^{2}\right)$ was higher in crossbreed male lambs comparing to the purebred male lambs $(P=0.025)$ but was not significantly different in purebred and crossbred female lambs. This area in CF lambs was lower than CM lambs $(P=$ 0.0002). Weights of brisket, flank, fat tail and fat thickness and weights of thigh, hand, loin, brisket, fat tail, total fat half-carcass with fat tail and bone as a percentage of cold half-carcass weight were not diverse among experimental lambs. Meat chemical composition measured of the purebred and crossbred lambs was presented at Table 5. The DM, CP, Ash and CF of meat in purebred and crossbred lambs were not different. Protein content of meat in CM lambs was higher than CF lambs $(P=0.013)$ but meat Ash content in CM lambs was lower than CF lambs $(P=0.001)$. Dry matter and Ash content of meat in GF lambs were greater than $\mathrm{CF}$ lambs $(P<0.0001$ and $P=0.001$ respectively $)$.

\section{Discussion}

\section{Growth performance and dry matter intake}

Crossbreeding had noticeable impact on feed intake for both male and female because of effect of the hybrid vigor that may occur in the F1 generation. Crossbreeding Lori-Bakhtiari and Romanov (Khaldari and Ghiasi 2018) and Awassi and Charollais (Abdullah et al. (2010) improved feed intake of the lambs, but Hassan et al. (1996) and Talebi and Gholamhosani (2017) indicated that DMI was not affected by crossbreeding. The interaction effect between genotype and sex for feed intake was significant and it 
shows that sex can be affected by genotype effect. Therefore by crossbreeding, DMI in crossbred female lambs (CF) increased compared to purebred male and female lambs (GM and GF). The ADG in experimental male lambs was in the range of $203.19-242.42 \mathrm{~g} / \mathrm{d}$ in our study which was in line to lambs (211-240 g/d) (Eilami 2008). The advantage of crossbreeding compared to pure breeding for animal growth and feed conversion ratio has been reported in many studies (Abdullah et al. 2010; Kutluca Korkmaz and Emsen 2016). In our study crossbreeding had positive influence on final BW and ADG in male and female lambs and crossbred male and female lambs had $10.3 \%$ and $9.65 \%$ higher final weight and $20.9 \%$ and $40 \%$ more ADG compared to purebred male and female lambs. Results of another research indicated about $25 \%$ and $23 \%$ increase for ADG in crossbred lambs compared to the purebred lambs (Fathala et al. 2014; Dvalishvili et al. 2015). In contrast to our results, Khaldari and Ghiasi (2018) described that purebred lambs of Lori-Bakhtiari had more final BW and ADG comparing to the crossbreed lambs Lori-Bakhtiari with Romanov breed. It appears that the preference of crossbred fattening lambs compared to purebred probably depends on the influence of heterosis (hybrid vigor), breed complementarity and the puberty weight (Schiller et al. 2015; Dvalishvili et al. 2015; Khaldari and Ghiasi 2018). However, variations among studies point out that the ADG can be different as a result of herd history, managing, ration structure, protein and energy content of feed, animal age, time of fattening and type of crossing between diverse sire and dam (Abdullah et al. 2010; Khaldari and Ghiasi 2018). Sex has important impact on body weight, that males have greater weight and gain compared to females. Androgens such as the testosterone seem to have a more stimulatory influence than estrogens, and this effect can be reason for differences in body weight between males and females. The stimulatory impact of androgens on growth are in part due to their ability to increase the secretion of growth hormone (Clarke et al. 2012).

The FCR was not affected by crossbreeding because DMI and ADG were increased in parallel. Similar to our result, Talebi and Gholamhosani (2017) stated that there was no significant difference among purebred and crossbred lambs for FCR. However, Hassan et al. (1996) compared crosses of Chios and Ossimi breeds and described that genotype of animal influenced on the FCR but had not any impact on feed consumption. The improved FCR in male lambs compared to the female lambs (especially in crossbred lambs with lower DMI) can be due to the sex effect. This superiority could be described by effect of steroid hormones because testosterone stimulates increasing of body mass (Grube 2018; Kelly and Jones 2013). Also this hormone could made variances in the structure of body weight improvement because the expansion of adipose tissue happens late in males compared to female lambs (Vargas Junior et al. 2014). Similarly, another studies were shown superiority of male compared to female for FCR (Hammell and Laforest 2000; Vargas Junior et al. 2014; Jaborek et al. 2018).

\section{Carcass Traits Data Of Crossbreed And Non-crossbreed Lambs}

With regarding to the any effect of crossbreeding on total hard and soft drops (Table 3), improvement in $\mathrm{HCW}$ and CCW in crossbred compared to purebred lambs can be directly by carcass weight increment. 
However effect of crossbreeding in studies was inconsistent. In agreement with our results Abdullah et al. (2010) and Esenbuga et al. (2001) showed improvement in gain, Khaldari and Ghiasi (2018) concluded gain decrease and Vargas Junior et al. (2014) observed any gain. The HCW and CCW in male and female of purebred lambs were not different but crossbreed males had greater carcass weight compared to crossbreed females. This point can be explained by differences in gain composition, because female carcasses contained more fat content than intact male carcasses. In agreement Abdullah et al. (2010) described that carcass weight of purebred male and female was not different but crossbreeding increased this weight in male lambs. However in other study had shown that carcass weight in purebred male lambs was greater than female lambs but crossbreed male and female lambs had similar carcass weight (Rodríguez et al. 2011).

The fat deposition in the body or tail compared to lean production requires more energy and therefore can be effective on FCR. In order to decrease the fat-tail, some studies have been conducted to reduce the size of the fat-tail by crossbreeding (Kashan et al. 2005; Dvalishvili et al. 2015; Khaldari and Ghiasi 2018). The extent of the fat-tail is affected by genetic and the feeding management of animals. The Ghezel breed have a big fat tail, approximately $5 \mathrm{~kg}$ (Izedifard and Dadpasand 2009), and Grey breed is considered by a low proportion of carcass fat and moderate fat tail (Farid 1991). In our study, crossbred and purebred lambs had any different for IFW, IFW as a percentage of live body weight, fat tail weight, fat tail weight as a percentage of cold half-carcass, but crossbreeding decreased fat tail compared to Ghezel male lambs in study by Izedifard and Dadpasand (2009). Similar to our work, Izedifard and Dadpasand (2009) reported that IFW, IFW as a percentage of live body weight, fat tail weight, fat tail weight as a percentage of cold half-carcass weight in crossbred and purebred lambs of Ghezel and Mehraban breed were not different. In contrast to our result, Khaldari and Ghiasi (2018) concluded that purebred lambs of LoriBakhtiari had heavier fat tail and total fat associated to the crossbreed lambs Lori-Bakhtiari with Romanov breed. Additionally, it has been shown in some research works that crossbreeding decreased total body fat content compared to the pure breeding (Abdullah et al. 2010; Blasco et al. 2019). The IFW, IFW as a percentage of live body weight in female lambs was higher compared to males lambs because regulation of adiposity and muscularity has been attributed to sexual steroid hormones and testosterone promotes an increase in body mass (Araújo et al. 2017). In agreement Rodríguez et al. (2011) and Kashan et al. (2005) indicated female carcasses contained more fat content than intact male carcasses.

Total hard drops, hide and feet were not affected by crossbreeding because the most effect of crossbreeding was on carcass gain. Similarly, in other works reported that weight of hard drops were not different in purebred and crossbred lambs (Kashan et al. 2005; Ünal et al. 2006). However, it has been reported in another work that weights of feet and hide in crossbred lambs were lesser than those of purebred lambs (Khaldari and Ghiasi 2018). Sex of lamb's effect on weight of total hard drops, head, hide and feet and heavier weight of these organs in male lambs can be due to more growth of males. In consist other studies had shown higher weight of hard drop in male lambs related to female lambs (Abdullah et al. 2010; Seyedsharifi and Hamzehzadeh 2016; Khaldari and Ghiasi 2018). However, these differences among studies can be due to gender, age, breed dissimilarity, structure of ration and slaughtering characteristics (Peña et al. 2005; Landim et al. 2011). 
Weight of total soft drops not affected by crossbreeding except for heart and spleen weight which was greater in crossbred male lambs in comparing to purebred male lambs. Our results were like to the some other studies (Kashan et al. 2005; Tsegay et al. 2013; Khaldari and Ghiasi 2018). It has been reported in some research works that heart weight is affected by the lamb's genotype and in crossbred lambs is higher than in pure lambs (Kashan et al. 2005; Abdullah et al. 2010).

Similar to our result, it has been reported that sex can affect these soft drops with superiority of male lambs (Kashan et al. 2005; Abdullah et al. 2010). In contrast, Jaborek et al. (2018) concluded that influence of sex on weight of heart, rumen, liver and spleen in Dorset $\times$ Hampshire lambs was not significant.

Crossbreeding increased thigh, hand, loin and neck weight $(\mathrm{kg})$ in male lambs but had no effect on female lambs. Similarly Seyedsharifi and Hamzehzadeh (2016) described that crossbred lambs of Chaal and Varamini had higher hand weight compared to Varamini pure lambs. However, weights of brisket and flank were not affected by crossbreeding. Similar to our result, other studies also reported lack of influence of crossbreeding on these carcass characteristics (Ünal et al. 2006; Abdullah et al. 2010; Khaldari and Ghiasi 2018). In contrast, Kashan et al. (2005) showed that crossbred lambs had higher weight of brisket and shoulder compared to the pure lambs.

Effect of sex on loin and neck weight was significant in crossbred lambs so that these weights in male lambs were higher than in female lambs. Sex associated differences in these weights may be due to physiological reasons that make males to grow faster (Wylie et al. 1997). Similarly, other works have shown greater weight of loin and neck in male lambs compared to female lambs (Kashan et al. 2005; Seyedsharifi and Hamzehzadeh 2016; Araújo et al. 2017). On the other hand, weights of thigh, brisket and flank were not affected by sex. In contrast to our result, it has been reported in some studies that sex effect on these carcass characteristic was important and in male lambs was greater than in female lambs (Malik et al. 1996; Seyedsharifi and Hamzehzadeh 2016). Crossbred male lambs had more lean weight $(16.13 \%)$ than purebred lambs and crossbred male and female lambs have approximately $11.23 \%$ and $19 \%$ more bone than purebred lambs in due to hybrid vigor. Similar to our result, Seyedsharifi and Hamzehzadeh (2016) and Khaldari and Ghiasi (2018) showed that crossbred lambs had greater lean meat compared to the purebred lambs but bone weight was not affected by crossbreeding. However, Kashan et al. (2005) illustrated that lean meat in purebred Chaal and Zandi lambs was similar to crossbred Zel $\times$ Chaal and Zel $\times$ Zandi lambs but bone weight was lower in purebred Chaal and Zandi compared to crossbred Zel $\times$ Chaal lambs. The fat thickness was not different among the experimental lambs. Similarly, Vargas Junior et al. (2014) described that impact of sex and crossbreeding in Pantaneiro and Texel lambs on fat thickness was not significant. Additionally, another work has shown that fat thickness in male and female lambs was not different (Flakemore et al. 2015). Nevertheless, Jaborek et al. (2018) and Mazon et al. (2017) exhibited that sex effect on this trait was significant and in male lambs was higher than in female lambs. Measuring of M. Longissimus dorsi can be important because of a great correlation among the traits of Longissimus dorsi and the carcass segments (Yarali et al. 2014). The LD area in crossbred male lambs was higher than purebred male lambs but difference in 
crossbred and purebred female lambs was not significant. In contrast to our result other studies showed that crossbreeding had no influence on LD area in crossbred and purebred lambs (Kashan et al. 2005; Vargas Junior et al. 2014). Influence of sex on LD area was significant only in crossbred male and female lambs nevertheless was similar in purebreds. Similar to our study, results of some research works have shown important differences in LD zone in male and female crossbred lambs (Kashan et al. 2005; Araújo et al. 2017). In contrast, Jaborek et al. (2018) in crossbred Dorset $\times$ Hampshire lambs and Vargas Junior et al. (2014) in crossbred Pantaneiro $\times$ Texel lambs concluded that the LD area not affected by sex.

Crossbreeding had no effect on DM, CP, Ash and EE of male and female lamb's meat. Effect of crossbreeding on meat chemical composition among studies is different. In another work had shown that DM, CP and Ash of meat in purebred and crossbred lambs were not different but purebred lambs had the lowest intramuscular fat percentage compared to crossbred lambs (Abdullah et al. 2010). Kashan et al. (2005) described that the percentage of CP in the meat of crossbred lambs was greater than purebred lambs but EE\% was lower and DM and Ash percentage were not different. Sex dependent effects on meat chemical composition were observed in lambs, with the exception of fat content, in disagreement with Rodríguez et al. (2011). Testosterone hormone, besides providing an anabolic influence acts on plasma glucose concentrations in males but does not modify the phosphorylation of AMP-activated protein kinase in muscle, which effects the concentration of intramuscular fat in males to a minor amount. A parallel result was detected in this study because the percentage of meat fat was similar between the male and female sexes (Clarke et al. 2012; Araújo et al. 2017).

\section{Conclusions}

Crossbreeding Grey Shirazi ewes with Ghezel rams improved dry matter intake and growth performance in male and female lambs. Some of Carcass trait was improved by crossbreeding especially in male lambs. Sex effect on growth performance and carcass traits was noticeable and male lambs had superior growth. However it is suggested that in future studies effects of breeding between Grey Shirazi ram and Ghezel ewe would be tested.

\section{Declarations}

\section{Ethical Approval}

This study was approved by the Livestock Research Team at Investigation Organization of Animal Science, Iran and was conducted according to the guidelines of care and using animals in research work.

\section{Consent to Participate}

All authors agree to participate in the current work.

\section{Consent to Publish}


All authors agree to publish the findings of the current research.

\section{Funding information}

The authors did not receive support from any organization for the submitted work.

\section{Competing Interests}

The authors will approve that there is no identified conflicts of interest related to this publication.

\section{Availability of data and material}

Not applicable

\section{Code availability}

Not applicable

\section{Authors' contributions}

A Karimi conceptualization, methodology, investigation, detection and analysis; MJ Abarghuei validation, participating writing, and revision and editing the original draft, and supervision A Boostani coorperation, contribute to design and management of work.

\section{References}

1. Abdullah, A.Y., Kridli, R.T., Shaker, M.M. and Obeidat, M.D., 2010. Investigation of growth and carcass characteristics of pure and crossbred Awassi lambs. Small Ruminant Research, 94, 167-175.

2. AOAC (Association of Official Analytical Chemists), 1990. Official Methods of Analysis, 16th edition. AOAC, Arlington VA, USA.

3. Araújo, T.L.A.C., Pereira, E.S., Mizubuti, I.Y., Campos, A.C.N., Pereira, M.W.F., Heinzen, E.L., Magalhães, H.C.R., Bezerra, L.R., da Silva, L.P. and Oliveira, R.L., 2017. Effects of quantitative feed restriction and sex on carcass traits, meat quality and meat lipid profile of Morada Nova lambs. Journal of Animal Science and Biotechnology, 8, 1-12.

4. Blasco, M., Campo, M.M., Balado, J. and Sañudo, C., 2019. Effect of Texel crossbreeding on productive traits, carcass and meat quality of Segureña lambs. Journal of the Science of food and Agriculture, 99, 3335-3342.

5. Caro, I., Alaiz-Rodríguez, R., González-Castro, V., Quinto, E.J. and Mateo, J., 2018. Conformation characteristics of suckling lambs carcasses from the Spanish local breeds Churra and Castellana and the non-native breed Assaf determined using digital photographs. Small Ruminant Research, 160, 89-94.

6. Caro-Petrović, V., Petrović, P.M., llić, Z.Z., Petrović, M.M., Ružićmuslić, D., Maksimović, N., Selionova, M.I. and Mandić, V., 2015. Crossing system application and its effect on lambs growth traits. 
Biotechnology in Animal Husbandry, 31 (4), 505-514.

7. Clarke, S.D., Clarke, I.J., Rao, A., Cowley, M.A. and Henry, B.A., 2012. Sex Differences in the Metabolic Effects of Testosterone in Sheep. Endocrinology, 153, 123-131.

8. Dvalishvili, V.G., Fathala, M.M., Vinogradov, I.S. and Dawod, A., 2015. Influence of Crossbreeding Romanov Ewes with Crossbred Argali Romanov Rams on Male Progeny Performance and Carcass Traits. Journal of Veterinary Science \& Technology, 6, 2-6.

9. Eilami, B., 2008. Substitution of alfalfa hay with Prangos ferulaceain the fattening diet of gray Shirazy sheep. Animal Science Journal, 79, 52-57.

10. Esenbuga, N., Macit, M., Karaoglu, M., Aksakal, V., Aksu, M.I., Yoruk, M.A. and Gul, M., 2009. Effect of breed on fattening performance, slaughter and meat quality characteristics of Awassi and Morkaraman lambs. Livestock Science, 123, 255-260.

11. Esenbuga, N., Yanar, M. and Dayioglu, H., 2001. Physical, chemical and organoleptic properties of ram lamb carcasses from four fat-tailed genotypes. Small Ruminant Research, 39, 99-105.

12. Farid, A., 1991. Carcass physical and chemical composition of three fat-tailed breeds of sheep. Meat Science, 29, 109-120.

13. Fathala, M.M., Dvalishvili, V.G. and Loptev, P.E., 2014. Effect of crossbreeding Romanov ewes with Edilbai rams on growth performance, some blood parameters and carcass traits. Egyptian Journal of Sheep \& Goat Sciences, 9, 1-7.

14. Fernández, C., López-Saez, A., Gallego, L. and de la Fuente, J.M., 2000. Effect of source of betaine on growth performance and carcass traits in lambs. Animal Feed Science and Technology, 86, 71-82.

15. Flakemore, A.R, Otto, J.R, Suybeng, B., Balogun, R.O., Malau-Aduli, B.S., Nichols, P.D. and Malau-Aduli, A.E.O., 2015.Performance and Carcass Characteristics of Australian Pure bred and Cross bred Lambs Supplemented with Rice Bran. Journal of Animal Science and Technology, 57(36), 20-29.

16. Grube, L.K., 2018. The effects of sex, breed, and slaughter weight on growth, carcass, and sensory characteristics of lamb. A Thesis Submitted to the Graduate Faculty of the North Dakota State University of Agriculture and Applied Science.

17. Hammell, K.L. and Laforest, J.P., 2000. Evaluation of the growth performance and carcass characteristics of lambs produced in Quebec. Canadian Journal of Animal Science, 80, 25-33.

18. Hassan, A.H., Fahmy, S.T.M., Mousa, M.T. and Suliman, A.I.A., 1996. The effect of crossbreeding between Chios and Ossimi sheep on growth performance and carcass characteristics of male lambs. Egyptian Journal of Animal Production, 33, 61-70.

19. Hosseinzadeh, S., Rafat, S.A., Moghaddam, Gh., Shodja, J/, Nematollahi, A., Shamsuddin, M., Periasamy, K. and Ebrahimi, M., 2016. Microsatellite Polymorphism in DRB2 gene and its relation to Haemonchus Contortus parasites fecal egg count in Iranian Ghezel sheep. Iranian Journal of Ruminants Health Research, 1(1), 31-39.

20. Ibarra, D., Laborde, D. and Van Lier, E., 2000. Repeatability and relationship with field mating performance of a serving capacity pen test in rams. Small Ruminant Research, 37, 165-169. 
21. Izedifard, J. and Dadpasand, M.R., 2009. Fattening performance and carcass composition of Ghezel and Mehraban and their crossed lambs. Iranian Journal of Animal Science, 40, 59-66.

22. Jaborek, J.R., Zerby, H.N., Moeller, S.J. and Fluharty, F.L., 2018. Effect of energy source and level, and sex on growth, performance, and carcass characteristics of long-fed lambs. Small Ruminant Research, 167, 61-69.

23. Kashan, N.E.J., Manafı Azar, G.H., Afzalzadeh, A. and Salehi, A., 2005. Growth performance and carcass quality of fattening lambs from fat-tailed and tailed sheep breeds. Small Ruminant Research, 60, 267-271.

24. Karimi, A. and Rahmani, R., 2017. Comparison of technical and economic indices of Grey Shirazi fattening lamb with Ghezel and Grey Shirazi crossbred lamb in Fars Province. Agricultural Research, Education and Extension Organization Fars Agricultural and Natural Resources Research and Education Center.

25. Kelly, D.M. and Jones, T.H., 2013. Testosterone: a metabolic hormone in health and disease. Journal of Endocrinology, 217, 25-45.

26. Khaldari, M. and Ghiasi, H., 2018. Effect of crossbreeding on growth, feed efficiency, carcass characteristics and sensory traits of lambs from Lori-Bakhtiari and Romanov breeds. Livestock Science, 214, 18-24.

27. Kutluca Korkmaz, M. and Emsen, E., 2016. Growth and reproductive traits of purebred and crossbred Romanov lambs in Eastern Anatolia. Animal Reproduction, 13, 3-6.

28. Landim, A.V., Castanheira, M., Fioravanti, M.C.S., Pacheco, A., Cardoso, M.T.M., Louvandini, H. and McManus, C., 2011. Physical, chemical and sensorial parameters for lambs of different groups, slaughtered at different weights. Tropical Animal Health and Production, 43, 1089-1096.

29. Makarechian, M., Farid, A. and Goshtasbpour-Parsi, B., 1978., A study of sheep breed differences in utilizing feed high in wheat straw. Iranian Journal of Agricultural Research, 6(2), 107-115.

30. Mahmoud Marai, I., Daader, A. and Bahgat, L., 2009. Performance trait of purebred Ossimi and Rahmani lambs and their crosses with Finn sheep born under two accelerated mating systems. Achieves of Animal Breeding, 52, 497-511.

31. Malik, R.C., Razzaque, M.A., Abbass, S., Al-Mutawa, T. and Al-Khozam, N., 1996. Breeding Australian crossbred ewes with Arabian Fat tailed rams for intensive lamb productin. Australian Journal of Experimental Agriculture, 36(1), 31-36.

32. Mazon, M.R., Carvalho, R.F., Pesce, D.M.C., Gallo, S.B. and Leme, P.R., 2017. Time on feedlot and sexual effects on animal performance and characteristics of lamb's meat. Acta Scientiarum. Animal Sciences, 39, 103-109.

33. Nasiriyan, A., Haji Seyed Javadi, S.M.M., Abbasi, M. and Eghbali, M., 2009. Atlas of animal breeds (cattle, sheep, goat, and horse) in the world and Iran. First ed. Gholami publisher. Pp: 286.

34. Notter, D.R., Mousel, M.R., Leeds, T.D., Taylor, J.B., Kirschten, D.P. and Lewis, G.S., 2012. Evaluation of Columbia, USMARC Composite, Suffolk, and Texel rams as terminal sires in an extensive rangeland 
production system: II. Post weaning growth and ultrasonic measures of composition. Journal of Animal Science, 90, 2941-2952.

35. NRC, 2007. Nutrient Requirements of Small Ruminants: Sheep, Goats, Cervids, and New World Camelids. Natl. Acad. Press, Washington, DC.

36. Peña, F., Cano, T., Domenech, V., Alcalde, M.J., Martos, J., Garcia-Martinez, A., Herrera, M. and Rodero, E., 2005. Influence of sex, slaughter weight and carcass weight on "noncarcass" and carcass quality in Segureña lambs. Small Ruminant Research, 60, 247-254.

37. Robertson, J.B and Van Soest, P.J., 1981. The detergent system of analysis. In: James, W.P.T., Theander, O. (Eds.), The Analysis of Dietary Fiber in Food, vol. 158., Marcel Dekker, New York, NY, USA, Basel, Switzerland, pp. 123. (Chap. 9).

38. Rodríguez, A.B., Bodas, P., Landa, R., López-Campos, Ó., Mantecón, A.R. and Giráldez, F.G., 2011. Animal performance, carcass traits and meat characteristics of Assaf and Merino $\times$ Assaf growing lambs. Livestock Science, 138, 13-19.

39. SAS, 2001 Statistical Analysis System. User's Guide: Statistics. Version 8.2. SAS Institute, Cary, NC, USA.

40. Schiller, K., Grams, V. and Bennewitz, J., 2015. Analysis of growth and feed conversion in purebred and crossbred German Merino lands chaf lambs. Archives Animal Breeding, 58, 177.

41. Seyedsharifi, R. and Hamzehzadeh azar, A., 2016. Evaluation of Slaughtered lambs Results from Varamini Ewes Crossing with Shal, Afshar, Moghani and Varamini Rams. Iranian Journal of Animal Science Research, 8(1), 174-185.

42. Talebi, M.A. and Gholamhosani, K., 2017. Growth and Feedlot Performance of Lori-Bakhtiari, Romanov $\times$ Lori-Bakhtiari and Pakistani $\times$ Lori-Bakhtiari Crossbred Lambs. Research on Animal Production, 8, 201-208.

43. Tsegay, T., Yoseph, M. and Mengistu, U., 2013. Comparative evaluation of growth and carcass traits of indigenous and crossbred (Dorper $\times$ Indigenous) Ethiopian Sheep. Small Ruminant Research, 114, 247-252.

44. Ünal, N., Akçapinar, H., Aytaç, M. and Atasoy, F., 2006. Fattening performance and carcass traits in crossbred ram lambs. Medycyna Weterynaryjna, 62, 401-404.

45. Van Soest, P.J., Robertson, J.B. and Lewis, B.A., 1991. Methods for dietary fiber, neutral detergent fiber and non-starch polysaccharides in relation to animal nutrition. Journal of Dairy Science, 74 , 3583-3597.

46. Vargas Junior, F.M., Martins, C.F., Pinto, G.D.S., Ferreira, M.B., Ricardo, H.D.A., Leão, A.G., Fernandes, A.R.M. and Teixeira, A., 2014. The effect of sex and genotype on growth performance, feed efficiency, and carcass traits of local sheep group Pantaneiro and Texel or Santa Inês crossbred finished on feedlot. Tropical Animal Health and Production, 46, 869-875.

47. Yarali, E., Yilmaz, O., Cemal, I., Karaca, O. and TAŞKIN, T., 2014. Meat quality characteristics in Kıvırcık lambs. Turkish Journal of Veterinary and Animal Science, 38, 452-458. 
48. Wylie, A.R.G., Chestnutt, D.M.B. and Kilpatrick, D.J., 1997 Growth and carcass characteristics of heavy slaughter weight lambs: effects of sire breed and sex of lamb and relationships to serum metabolites and IGF-1. Animal Science, 64, 309-318.

\section{Tables}

\section{Table 1}

Ingredients and chemical composition of the experimental diet ${ }^{1}$

\section{Ingredients (g/kg DM)}

\begin{tabular}{|c|c|}
\hline Alfalfa hay & 250 \\
\hline Corn silage & 80 \\
\hline Wheat straw & 140 \\
\hline Soybean meal, $44 \%$ CP & 70 \\
\hline Barley, rolled & 450 \\
\hline Mineral and vitamin premix ${ }^{2}$ & 5 \\
\hline Salt & 5 \\
\hline \multicolumn{2}{|l|}{ Chemical composition ( $g / k g ~ D M)$} \\
\hline DM (g/kg, as-fed basis) & 853.5 \\
\hline OM & 917.3 \\
\hline $\mathrm{CP}$ & 134.9 \\
\hline EE & 19.8 \\
\hline ME (Mcal/kg DM) & 2.40 \\
\hline NDFom & 369.5 \\
\hline ADFom & 229.8 \\
\hline ADL & 41.7 \\
\hline \multicolumn{2}{|c|}{$\begin{array}{l}{ }^{1} \text { Basal diet Calculated from (NRC) National Research Council (2007); }{ }^{2} \text { Premix contained (per kg): Ca } \\
(120 \mathrm{~g}), \mathrm{P}(30 \mathrm{~g}), \mathrm{Na}(55 \mathrm{~g}), \mathrm{Mg}(20 \mathrm{~g}), \mathrm{Zn}(3 \mathrm{~g}), \mathrm{Fe}(3 \mathrm{~g}), \mathrm{Mn}(2 \mathrm{~g}), \mathrm{Cu}(280 \mathrm{mg}), \mathrm{Co}(100 \mathrm{mg}), \mathrm{Se}(1 \\
\mathrm{mg}), \mathrm{K}(215 \mathrm{mg}), \mathrm{I}(100 \mathrm{mg}) \text {, vitamin E }(100 \mathrm{mg}) \text {, vitamin A (500,000 IU), vitamin D3 (100,000 IU), } \\
\text { antioxidant }(400 \mathrm{mg}) \text {, carrier, up to } 1000 \mathrm{~g} \text {. }\end{array}$} \\
\hline NDFom ash-free NDF, ADFom & \\
\hline
\end{tabular}


Table 2

Feed intake and live weight of purebred and crossbred lambs $(n=48)$

\begin{tabular}{|c|c|c|c|c|c|c|}
\hline \multicolumn{7}{|c|}{ Ingredients } \\
\hline \multicolumn{2}{|l|}{ Lambs } & Intake (g/d) & Initial BW (kg) & Final BW (kg) & ADG (g) & FCR \\
\hline \multicolumn{2}{|l|}{ GM } & $1365.55^{b}$ & 28.83 & $42.39^{b c}$ & $203.41^{b}$ & $6.77^{b}$ \\
\hline \multicolumn{2}{|l|}{ GF } & $1258.68^{b}$ & 27.78 & $39.90^{c}$ & $146.41^{c}$ & $8.59^{a}$ \\
\hline \multicolumn{2}{|l|}{$\mathrm{CM}$} & $1547.44^{\mathrm{a}}$ & 28.50 & $46.75^{\mathrm{a}}$ & $245.95^{a}$ & $6.35^{\mathrm{b}}$ \\
\hline \multicolumn{2}{|l|}{$\mathrm{CF}$} & $1672.43^{\mathrm{a}}$ & 28.42 & $43.75^{b}$ & $204.98^{\mathrm{ab}}$ & $8.04^{\mathrm{a}}$ \\
\hline \multicolumn{2}{|l|}{ SEM } & 51.428 & 0.66 & 0.962 & 14.284 & 0.24 \\
\hline \multirow[t]{3}{*}{$P$ value } & G & $<0.0001$ & 0.916 & 0.0005 & 0.002 & 0.204 \\
\hline & S & 0.850 & 0.690 & 0.011 & 0.003 & $<0.0001$ \\
\hline & $G \times S$ & 0.037 & 0.734 & 0.829 & 0.595 & 0.808 \\
\hline \multicolumn{7}{|c|}{$\begin{array}{l}\text { GM purebred male lambs of Grey Shirazi ewe } \times \text { Grey Shirazi ram, GF purebred female lambs of Grey } \\
\text { Shirazi ewe } \times \text { Grey Shirazi ram, } C M \text { crossbred male lambs of Grey Shirazi ewe } \times \text { Ghezel ram, } C F \\
\text { crossbred female lambs of Grey Shirazi ewe } \times \text { Ghezel ram, } A D G \text { average daily gain, FCR feed } \\
\text { conversion ratio (g DMI/g ADG), SEM standard error of the means, } n \text { number of experimental lambs, } G \\
\text { genotype effect, } S \text { sex effect, abc Mean values in columns which do not have a common superscript } \\
\text { letter are significantly different }(P<0.05) \text {. }\end{array}$} \\
\hline
\end{tabular}


Table 3

Slaughtering and carcass characteristics data of purebred and crossbred lambs $(n=48)$

\section{Lambs}

SEM $P$ value

\begin{tabular}{lllllllll} 
& GM & GF & CM & CF & & G & S & G $\times$ S \\
HCW (kg) & $20.25^{\mathrm{bc}}$ & $19.48^{\mathrm{c}}$ & $22.66^{\mathrm{a}}$ & $20.96^{\mathrm{b}}$ & 0.478 & 0.0007 & 0.021 & 0.349 \\
HCW (\% LBW) & 46.80 & 48.15 & 48.46 & 49.51 & 1.214 & 0.228 & 0.338 & 0.902 \\
CCW (kg) & $19.92^{\mathrm{bc}}$ & $19.18^{\mathrm{c}}$ & $22.29^{\mathrm{a}}$ & $20.63^{\mathrm{b}}$ & 0.488 & 0.001 & 0.025 & 0.366 \\
CCW (\% LBW) & 46.08 & 47.40 & 47.72 & 48.76 & 1.228 & 0.236 & 0.350 & 0.909 \\
\hline IFW (g) & $716^{\mathrm{b}}$ & $1140^{\mathrm{a}}$ & $677^{\mathrm{b}}$ & $1004^{\mathrm{a}}$ & 78.95 & 0.282 & 0.0001 & 0.538 \\
IFW (\% LBW) & $1.67^{\mathrm{c}}$ & $2.86^{\mathrm{a}}$ & $1.49^{\mathrm{c}}$ & $2.28^{\mathrm{b}}$ & 0.188 & 0.056 & $<0.0001$ & 0.250
\end{tabular}

Hard drops $(\mathrm{kg})$

$\begin{array}{lllllllll}\text { Hide } & 6.22^{\mathrm{a}} & 4.26^{\mathrm{b}} & 6.20^{\mathrm{a}} & 4.42^{\mathrm{b}} & 0.289 & 0.836 & <0.0001 & 0.783 \\ \text { Head } & 3.11^{\mathrm{a}} & 2.11^{\mathrm{c}} & 2.68^{\mathrm{b}} & 1.83^{\mathrm{c}} & 0.115 & 0.006 & <0.0001 & 0.539 \\ \text { Feet } & 1.10^{\mathrm{a}} & 0.823^{\mathrm{b}} & 1.11^{\mathrm{a}} & 0.83^{\mathrm{b}} & 0.038 & 0.889 & <0.0001 & 0.964 \\ \text { Total } & 10.61^{\mathrm{a}} & 7.20^{\mathrm{b}} & 9.99^{\mathrm{a}} & 7.06^{\mathrm{b}} & 0.370 & 0.305 & <0.0001 & 0.517\end{array}$

Soft drops

\begin{tabular}{lllllllll} 
Rumen & $1.29^{\mathrm{a}}$ & $0.9^{\mathrm{b}}$ & $1.19^{\mathrm{ab}}$ & $1.11^{\mathrm{ab}}$ & 0.088 & 0.820 & 0.036 & 0.197 \\
Kidneys & $0.12^{\mathrm{a}}$ & $0.08^{\mathrm{b}}$ & $0.13^{\mathrm{a}}$ & $0.09^{\mathrm{b}}$ & 0.007 & 0.209 & 0.0001 & 0.949 \\
\hline Lungs & $0.62^{\mathrm{ab}}$ & $0.53^{\mathrm{bc}}$ & $0.65^{\mathrm{a}}$ & $0.50^{\mathrm{c}}$ & 0.036 & 0.948 & 0.003 & 0.398 \\
\hline Spleen & $0.07^{\mathrm{b}}$ & $0.06^{\mathrm{b}}$ & $0.09^{\mathrm{a}}$ & $0.07^{\mathrm{b}}$ & 0.004 & 0.039 & 0.003 & 0.067 \\
\hline Heart & $0.18^{\mathrm{b}}$ & $0.16^{\mathrm{bc}}$ & $0.20^{\mathrm{a}}$ & $0.15^{\mathrm{c}}$ & 0.007 & 0.500 & $<0.0001$ & 0.008 \\
\hline Liver & $0.89^{\mathrm{a}}$ & $0.64^{\mathrm{b}}$ & $0.87^{\mathrm{a}}$ & $0.62^{\mathrm{b}}$ & 0.032 & 0.645 & $<0.0001$ & 0.922 \\
\hline Total & $3.16^{\mathrm{a}}$ & $2.42^{\mathrm{b}}$ & $3.12^{\mathrm{a}}$ & $2.53^{\mathrm{b}}$ & 0.140 & 0.831 & 0.0002 & 0.666
\end{tabular}

GM purebred male lambs of Grey Shirazi ewe $\times$ Grey Shirazi ram, GF purebred female lambs of Grey Shirazi ewe $\times$ Grey Shirazi ram, $C M$ crossbred male lambs of Grey Shirazi ewe $\times$ Ghezel ram, $C F$ crossbred female lambs of Grey Shirazi ewe $\times$ Ghezel ram, HCW hot carcass weight, HCW (\% LBW) hot carcass weight as a percentage of live body weight, CCW cold carcass weight, CCW (\% LBW) cold carcass weight as a percentage of live body weight, IFW internal fat weight, IFW (\% LBW) internal fat weight as a percentage of live body weight, $n$ number of experimental lambs, $n$ number of experimental lambs, SEM standard error of the means, $G$ genotype effect, $S$ sex effect, abc Mean values in rows which do not have a common superscript letter are significantly different $(P<0.05)$. 
Page 18/21 
Table 4

Slaughtering data of half-carcass of purebred and crossbred lambs $(n=48)$

Lambs

GM GF $\quad \mathrm{CM} \quad \mathrm{CF}$

$2.59^{b}$

$2.51^{\mathrm{b}}$

$2.94^{\mathrm{a}} \quad 2.88^{\mathrm{ab}}$

$25.96 \quad 26.35$

27.80

SEM

$P$ value

Thigh weight

Thigh weight (\%

26.60

$1.50^{\mathrm{b}}$

$1.88^{a}$

$1.69^{a b}$

0.073

G

$0.104 \quad 0.003$

S

$G \times S$

Hand weight

$1.55^{\mathrm{b}}$

15.33

16.00

16.72

16.12

0.543

0.878

0.361

0.559

0.939

CHCW)

Loin weight

$1.63^{b}$

$1.51^{\mathrm{b}}$

$1.94^{\mathrm{a}}$

$1.70^{\mathrm{b}}$

$0.071 \quad 0.005$

0.022

0.430

Loin weight (\%
CHCW)

16.42

15.50

17.20

16.33

0.561

0.159

0.156

0.900

Brisket weight

1.34

1.32

1.51

1.35

0.057

0.144

0.129

0.298

Brisket weight (\%

CHCW)

13.14

13.74

13.21

13.00

0.421

0.471

0.570

0.342

Flank weight

0.37

0.49

0.39

0.44

0.049

0.660

0.110

$0.549 \quad 0.227$

0.044

$4.20^{\mathrm{ab}}$

$5.34^{\mathrm{a}}$

$3.40^{\mathrm{b}}$

$0.74^{\mathrm{b}}$

$0.92^{\mathrm{a}}$

$0.72^{\mathrm{b}}$

$0.033 \quad 0.018$

0.013

0.003

Neck weight (\%

CHCW)

$7.12^{\mathrm{b}} \quad 7.73^{\mathrm{ab}}$

$8.20^{\mathrm{a}}$

$6.93^{\mathrm{b}}$

0.312

0.762

0.233

0.006

Fat tail weight

1.76

1.45

1.65

Fat tail weight (\% CHCW)

Total fat halfcarcass without fat tail (\% CHCW)

Total fat halfcarcass with fat tail (\% CHCW)

17.51

15.54

1.65

1.60

0.132

0.965

0.283

0.374

14.50

15.42

1.327

0.215

0.650

0.257

$10.45^{\mathrm{ab}}$

$12.52^{\mathrm{a}} \quad 9.82^{\mathrm{b}}$

$11.61^{\mathrm{ab}}$

0.836

0.395

0.036

0.839

28.00

28.00

$27.99 \quad 24.46$

27.03

1.327

0.108

0.340

0.352

GM purebred male lambs of Grey Shirazi ewe $\times$ Grey Shirazi ram, GF purebred female lambs of Grey Shirazi ewe $\times$ Grey Shirazi ram, CM crossbred male lambs of Grey Shirazi ewe $\times$ Ghezel ram, $C F$ crossbred female lambs of Grey Shirazi ewe $\times$ Ghezel ram, \% CHCW as a percentage of cold halfcarcass weight, $L D$ Longissimus dorsi, $n$ number of experimental lambs, SEM standard error of the means, $G$ genotype effect, $S$ sex effect, abc Mean values in rows which do not have a common superscript letter are significantly different $(P<0.05)$. 


\begin{tabular}{|c|c|c|c|c|c|c|c|c|}
\hline & Lambs & & & & SEM & $P$ value & & \\
\hline Lean weight & $5.64^{b}$ & $5.14^{b}$ & $6.55^{a}$ & $5.60^{\mathrm{b}}$ & 0.168 & 0.0006 & 0.0004 & 0.153 \\
\hline $\begin{array}{l}\text { Lean weight (\% } \\
\text { CHCW) }\end{array}$ & $55.78^{a b}$ & $53.22^{b}$ & $58.40^{a}$ & $53.64^{b}$ & 1.139 & 0.199 & 0.004 & 0.348 \\
\hline Bone weight & $1.87^{b}$ & $1.79^{b}$ & $2.08^{a}$ & $2.13^{\mathrm{a}}$ & 0.063 & 0.0003 & 0.623 & 0.298 \\
\hline $\begin{array}{l}\text { Bone weight (\% } \\
\text { CHCW) }\end{array}$ & 18.42 & 18.37 & 18.50 & 20.13 & 0.660 & 0.196 & 0.211 & 0.200 \\
\hline $\begin{array}{l}\text { Fat thickness } \\
(\mathrm{mm})\end{array}$ & 5.33 & 5.51 & 5.41 & 6.02 & 0.733 & 0.675 & 0.549 & 0.785 \\
\hline LD area $\left(\mathrm{cm}^{2}\right)$ & $11.12^{b}$ & $11.23^{b}$ & $12.97^{\mathrm{a}}$ & $10.59^{b}$ & 0.249 & 0.025 & 0.0002 & $<0.0001$ \\
\hline \multicolumn{9}{|c|}{$\begin{array}{l}\text { GM purebred male lambs of Grey Shirazi ewe } \times \text { Grey Shirazi ram, GF purebred female lambs of Grey } \\
\text { Shirazi ewe } \times \text { Grey Shirazi ram, } C M \text { crossbred male lambs of Grey Shirazi ewe } \times \text { Ghezel ram, } C F \\
\text { crossbred female lambs of Grey Shirazi ewe } \times \text { Ghezel ram, } \% \text { CHCW as a percentage of cold half- } \\
\text { carcass weight, } L D \text { Longissimus dorsi, } n \text { number of experimental lambs, SEM standard error of the } \\
\text { means, } G \text { genotype effect, } S \text { sex effect, abc Mean values in rows which do not have a common } \\
\text { superscript letter are significantly different }(P<0.05) \text {. }\end{array}$} \\
\hline
\end{tabular}


Table 5

Meat chemical composition of the purebred and crossbred lambs $(n=48)$

\begin{tabular}{|c|c|c|c|c|c|}
\hline \multicolumn{6}{|c|}{ Chemical composition (\%) } \\
\hline \multicolumn{2}{|l|}{ Lambs } & DM & $\mathrm{CP}$ & Ash & EE \\
\hline \multicolumn{2}{|l|}{ GM } & $42.83^{c}$ & $57.82^{\mathrm{ab}}$ & $1.40^{\mathrm{C}}$ & 40.78 \\
\hline \multicolumn{2}{|l|}{ GF } & $46.81^{a}$ & $56.70^{\mathrm{b}}$ & $1.63^{\mathrm{ab}}$ & 41.67 \\
\hline \multicolumn{2}{|l|}{$\mathrm{CM}$} & $44.08^{\mathrm{bc}}$ & $59.82^{\mathrm{a}}$ & $1.51^{\mathrm{bc}}$ & 39.01 \\
\hline \multicolumn{2}{|l|}{$\mathrm{CF}$} & $45.64^{\mathrm{ab}}$ & $56.98^{b}$ & $1.75^{\mathrm{a}}$ & 41.27 \\
\hline \multicolumn{2}{|l|}{ SEM } & 0.540 & 0.800 & 0.060 & 0.725 \\
\hline \multirow[t]{3}{*}{$P$ value } & G & 0.925 & 0.112 & 0.067 & 0.119 \\
\hline & S & $<0.0001$ & 0.013 & 0.001 & 0.124 \\
\hline & $G \times S$ & 0.038 & 0.424 & 0.913 & 0.088 \\
\hline \multicolumn{6}{|c|}{$\begin{array}{l}G M \text { purebred male lambs of Grey Shirazi ewe } \times \text { Grey Shirazi ram, } G F \text { purebred female lambs of Grey } \\
\text { Shirazi ewe } \times \text { Grey Shirazi ram, } C M \text { crossbred male lambs of Grey Shirazi ewe } \times \text { Ghezel ram, } C F \\
\text { crossbred female lambs of Grey Shirazi ewe } \times \text { Ghezel ram, } D M \text { dry matter, } C P \text { crude protein, } E E \text { ether } \\
\text { extract, } n \text { number of experimental lambs, } S E M \text { standard error of the means, } G \text { genotype effect, } S \text { sex } \\
\text { effect, abcMean values in rows which do not have a common superscript letter are significantly } \\
\text { different }(P<0.05) \text {. }\end{array}$} \\
\hline
\end{tabular}

